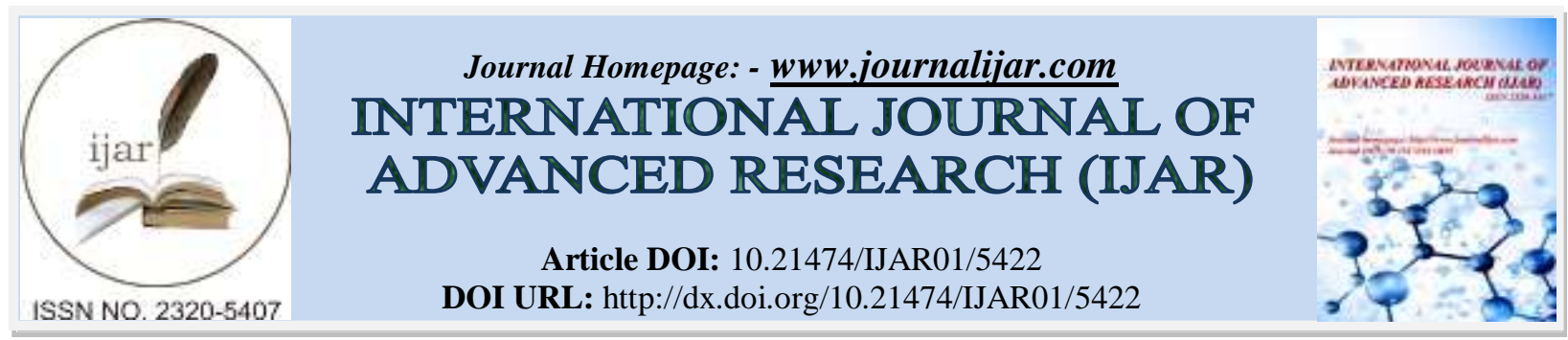

RESEARCH ARTICLE

\title{
STUDIES ON THE HOST RANGES OF ANGIOSPERM PARASITES Dendrophphoe falcata var. coccinia AND Cassytha filiformis IN ANNAMALAI RESERVE FOREST, THIRUNANNAMALAI, TAMIL NADU, INDIA.
}

\section{Pandian ${ }^{1}$, S. Natarajan ${ }^{2}$ and A. Stephen ${ }^{3}$.}

1. Research Scholar, Department of Plant Biology and Biotechnology, Guru Nanak College, Velachery, Chennai42, Tamil Nadu, India.

2. Associate Professor, Department of Plant Biology and Biotechnology, Guru Nanak College, Velachery, Chennai-42, Tamil Nadu, India.

3. Assistant Professor, School of Liberal Arts and Sciences, Trans-Disciplinary University, Bengaluru, India.

\section{Manuscript Info}

(...........................

Manuscript History

Received: 13 July 2017

Final Accepted: 15 August 2017

Published: September 2017

Key words:-

Angiosperm parasites; Mistletoe;

Dodder; Double Parasitism;

Polymorphism.

\section{Abstract}

This study pertains to the evaluation of host ranges of angiosperm parasites Dendrophthoe falcata (L.f.) Ettingsh var. coccinia (Talb.) Sant. (Loranthaceae) and Cassytha filiformis L. (Lauraceae) on various angiosperm host plants in the Annamalai reserve forest, Thiruvannamalai District, Tamil Nadu, India. D. falcata was found growing on five host trees belonging to four families of Dicotyledons in a localised area of the hill but $C$. filiformis had a wide range of 26 host plants belonging to 18 families of Dicotyledons which grew from the plains to thehill top. Study revealed that $C$. filiformis had managed to increase its host ranges rather than $D$. falcata. Polymorphism of leaves were also observed in $D$. falcata. Instances of double parasitism were found on Acacia chundra and Diospyros ferrea.

Copy Right, IJAR, 2017,. All rights reserved.

\section{Introduction:-}

About 4100 species of flowering plants belonging to 277 genera are reported to be parasitic on different host plants, out of which 25 genera can cause negative impacts (Nickrant and Musselman, 2004). Angiosperm parasites Dendrophthoe falcata var. coccinia (Loranthaceae) is otherwise called as misletoe and Cassytha filiformis (Lauraceae) also called as dodder cause serious problems for the hosts plants (Mathur, 1949). Dodder infests woody plants and also damages certain economically important crops. D. falcata grows on Mangifera indica L., Dalbergia sisso Roxb., Albizia lebbeck (L.) Benth. and Ficus benghalensis L. (Wellman, 1964) and also attacks horticultural and other woody angiosperms, viz., Punica granatum L., Callistemon lanceolatus (Sm.) Sweet., Psidium guajava L., Syzygium cumini (L.), Aegle marmelos (L.) Correa., Ficus religiosa L., Ficus rumphii Bl., Citrus maxima Merr. and Eucalyptus sp. These parasites never kill the host plants but they live unhappily together (Nickrent, 2002). D. falcata attacks on at least 110 tree species in Chennai (Brand, 1938). Anuradha (2005) had observed that infestation of D. falcata on 44 arborescent species in the forest of Shakthi Auroville of Tamil Nadu. It poses a serious loss to economically valuable horticultural plants and other valuable plants growing in forests, orchards or gardens (Sridhar and Rao, 1979). Madhuca latifolia is also a common host to misletoe (Mehrotra, 1983).

Cassytha filiformis is a leafless, vine-like, climbing and hemi-parasite which parasitizes on a wide variety of woody hosts including plants of agricultural, horticultural and economic values. The host ranges of $C$. filiformis is broad 
(Nickrent and Musselman, 2004). Nelson (2008) had stated that the parasite obtains nutrients and water from the host plants without quickly killing the host cells. The pathogen does not create immediate fatal damages to the host cells and their metabolic processes. Rather the host plants can die a long protracted death by starvation and desiccation. Heavy infections can eventually smoother and kill host plants. Cassytha filiformis is reported to be capable of transmitting phytoplasma from palms (Cocos nucifera L. and Areca catechu L.) and a viral disease such as citrus mosaic caused by citrus mosaic badna virus (Nelson, 2008). It is a common stem parasite of Lantana camera L. and Toddalia sp and certain other plants in south India (Rangaswamy and Rangan, 1963). Werth et al. (1979) had listed out 81 species which were affected by $C$. filiformis in the Bahamar, including grasses, ferns, gymnosperms as well as board-leaved angiosperms. Cassytha filiformis has a wide host ranges such as grasses, broad leaved angiosperms, ferns and gymnosperm (Mukhtar et al. 2010; Kokubugata and Yokota, 2012). In this parasite fruits are dispersed by birds (David et al., 2015). Balasubramanian (1990) noted that seeds were taken by white-browed bulbul (Pycnonotus luteolus). Following germination, the primary root fails to develop but adventitious roots may provide anchorage for a short period (Mahadevan and Jayasuriya, 2013). Seedlings can then survive up to eight weeks, without a host, growing to a length of $30 \mathrm{~cm}$ or more relying on the seed reserves (Nelson, 2008).

Thiruvannamalai district harbours rich vegetation including medicinal plants. Vijayasankar et al. (2010) have reported that 1365 taxa of angiosperms including 1278 species, 18 subspecies, 16 varieties in 713 genera spread over 158 families. Of these 1365 taxa, 1111 occur naturally and 254 taxa are cultivated in the district. About $80.5 \%$ taxa are dicots while the monocots are 19.5\%. Poaceae is the largest family comprising 60 genera and 108 species. The aim of the present study is to identify the habitats, host plants, extent of host ranges of two angiosperm parasites viz., D. falcata and C. filiformis, in the Annamalai reserve forest.

\section{Material and Methods:-}

\section{Study Area:-}

Thiruvannamalai District lies between $12^{\circ} 00^{\prime}$ and $12^{\circ} 49^{\prime} \mathrm{N}$ latitude $-78^{\circ} 38^{\prime}$ and $79^{\circ} 45^{\prime} \mathrm{E}$ longitude covering 6191 $\mathrm{km}^{2}$ with a human population of 24.68 lakh and is $185 \mathrm{~km}$ from Chennai $\left(13^{\circ} 5^{\prime} \mathrm{N}-80^{\circ} 17^{\prime} \mathrm{E}\right)$. The principal occupation of residents here is agriculture. Annamalai reserve forest, a part of the Eastern Ghats occurs between $12^{\circ}$ $11^{\prime} \mathrm{N}$ latitude and $79^{\circ} 02^{\prime} \mathrm{E}$ longitude with an extent of 699 hectares (Fig 1). Annamalai or Thiruvannamalai or Arunachala or Arunai hill denotes 'Holy fire hill'. Annual Karthigai Deepam is a very old festival and is observed in the Tamil month of Karthigai (mid-November to mid-December) on the day when the moon is in conjunction with the constellation Karthigai and Pournami. A huge fire lamp is lit up (Mahadeepam) on the hill top (814m above mean sea level) and it continues to be on fire for twelve days. The average annual precipitation for the past 20 years (1997-2016) is $1037.8 \mathrm{~mm}$. The forest experiences a maximum temperature of $38^{\circ} \mathrm{C}$ during summer and $20^{\circ} \mathrm{C}$ to $26^{\circ} \mathrm{C}$ winter. Geologically the Annamalai hill consists of Charnockite, Gneiss and Granite rocks. Southern tropical thorn forest flourishes on the plains and hills except on barren rocks.

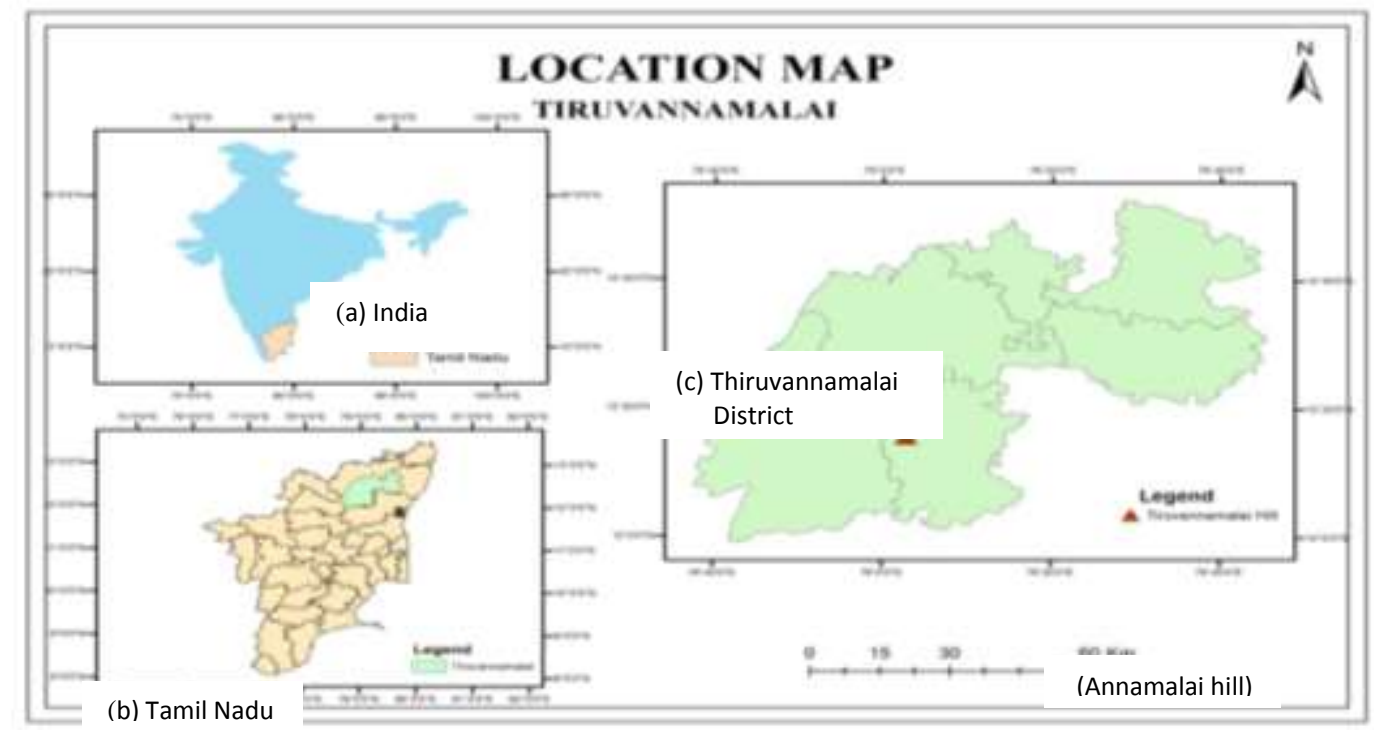

Fig 1:- Location Maps: (a). India, (b). Tamil Nadu and (c). Thiruvannamalai District showing Annamalai hill. 
We visited the study area between January 2016 and January 2017 covering all the four seasons. We laid 20 quadrats each measuring $10 \times 10 \mathrm{~m}$ and ensured a distance of 100 meters between two quadrats. We identified angiosperm parasites $D$. falcata and $C$. filiformis and enumerated and identified host plants in each quadrat to assess the host ranges of these two parasites. All the host plants were identified using "The Flora of Presidency of Madras" (Gamble and Fischer, 1959), "The Flora of Tamil Nadu Carnatic" (Mathew, 1983) "Flora of Tamil Nadu" (Nair, N. C. and Henry, A. N. 1989) and "Plant Resources of Tiruvannamalai District" (Vijayasankar et al. 2010). The leaf area of D. falcata was measured by using the Kemp formula (1960): Leaf area = L x B x K; Where, L= length of the leaf, $\mathrm{B}=$ Breadth and $\mathrm{K}=\mathrm{Kemp}$ 's constant ( 0.66 for Dicotyledons). Movements of sunbirds were observed between 0600 hours and 09.30 hours in the morning and 15.00 hours and 17.30 hours in the evening.

\section{Results and Discussion:-}

Dendrophthoe falcata produces tubular, bisexual and red coloured flowers arranged in spikes. Pollination is entomophilous because the red coloured perianth and nectar attracts insects. The seeds are carried and dispersed by sunbirds Cinnyris asiatica (Passeriformes: Nectariniidae)). Our study revealed that the parasite D. falcata was found growing on five host trees belonging to four families in undisturbed areas of the hill. The leaves of $D$. falcata exhibited polymorphism on different host plants. The shape and size of leaf lamina varies depending on the host plants on which it grows. (Fig 2 a, b \& c). The leaf areas of this parasite on various host trees were calculated using Kemp's formula. The maximum leaf area $\left(53.85 \mathrm{~cm}^{2}\right)$ was found in Azadirachta indica followed by Cassia fistula $\left(25.74 \mathrm{~cm}^{2}\right)$, Acacia chundra $\left(6.86 \mathrm{~cm}^{2}\right)$, Flacourtia ramontchi $\left(6.45 \mathrm{~cm}^{2}\right)$ and Acacia leucophloea $\left(5.77 \mathrm{~cm}^{2}\right)$.

Table 1:- Host trees of D. falcata in Annamalai reserve forest.

\begin{tabular}{|c|l|l|l|l|}
\hline S.No. & \multicolumn{1}{|c|}{ Host plant } & \multicolumn{1}{c|}{ Family } & Habit & Indigenous/exotic \\
\hline 1. & Azadirachta indica Adr.Juss. & Meliaceae & Tree & Indigenous \\
\hline 2. & Cassia fistula L. & Caesalpiniaceae & Tree & Indigenous \\
\hline 3. & Acacia leucophloea (Roxb.) Willd. & Mimosaceae & Tree & Indigenous \\
\hline 4. & $\begin{array}{l}\text { Acacia chundra (Roxb. Ex. Rottler) } \\
\text { Willd. }\end{array}$ & Mimosaceae & Tree & Indigenous \\
\hline 5. & Flacourtia ramontchi L'Her. & Flacourtiaceae & Tree & Indigenous \\
\hline
\end{tabular}

Selvi and Kadamban (2009) had observed that 26 species of angiosperms were infested by this parasite. Calvin and Wilson (2009) had stated that the parasite has rapidly increased its host range. However in the present study, $D$. falcata had infested five tree species belonging to four families, found in the undisturbed reserve forest and was absent in other parts of the human impacted forest, even though the host trees were found predominant (Table 1). It is observed that frequent movement of the general public and pilgrims to ashrams situated in the foot hills daily, particularly during festive seasons in the eastern, north-eastern and south-eastern sides of the hills, prevents the visit of sunbirds which were found active in dispersal of seeds from the fruits of D. falcata. The parasite, hence was found only in the undisturbed forest where sunbirds visit frequently. Visits of such birds on the parasite and consumption of its fruits were noticed during morning (06.00-10.00 hrs) and evening (15.00-17.30 hrs) in the undisturbed forest. This attributes that sunbirds were active in dispersal of the seeds in the undisturbed forests and hence D. falcata had confined its host ranges in a localised area and did not extend beyond five species. It had not infested any host plants belonging to Monocotyledons.

In C. filiformis also the fruits are dispersed by birds (David et al., 2015). Balasubramanian (1990) noted that seeds were taken by white-browed bulbul Pycnonotus luteolus (Passeriformes: Pycnonotidae). Following germination, the primary root fails to develop but adventitious roots may provide anchorage for a short period (Mahadevan and Jayasuriya, 2013). Seedlings can then survive up to eight weeks, without a host, growing upto a length of $30 \mathrm{~cm}$ or more relying on the seed reserves (Nelson, 2008). 

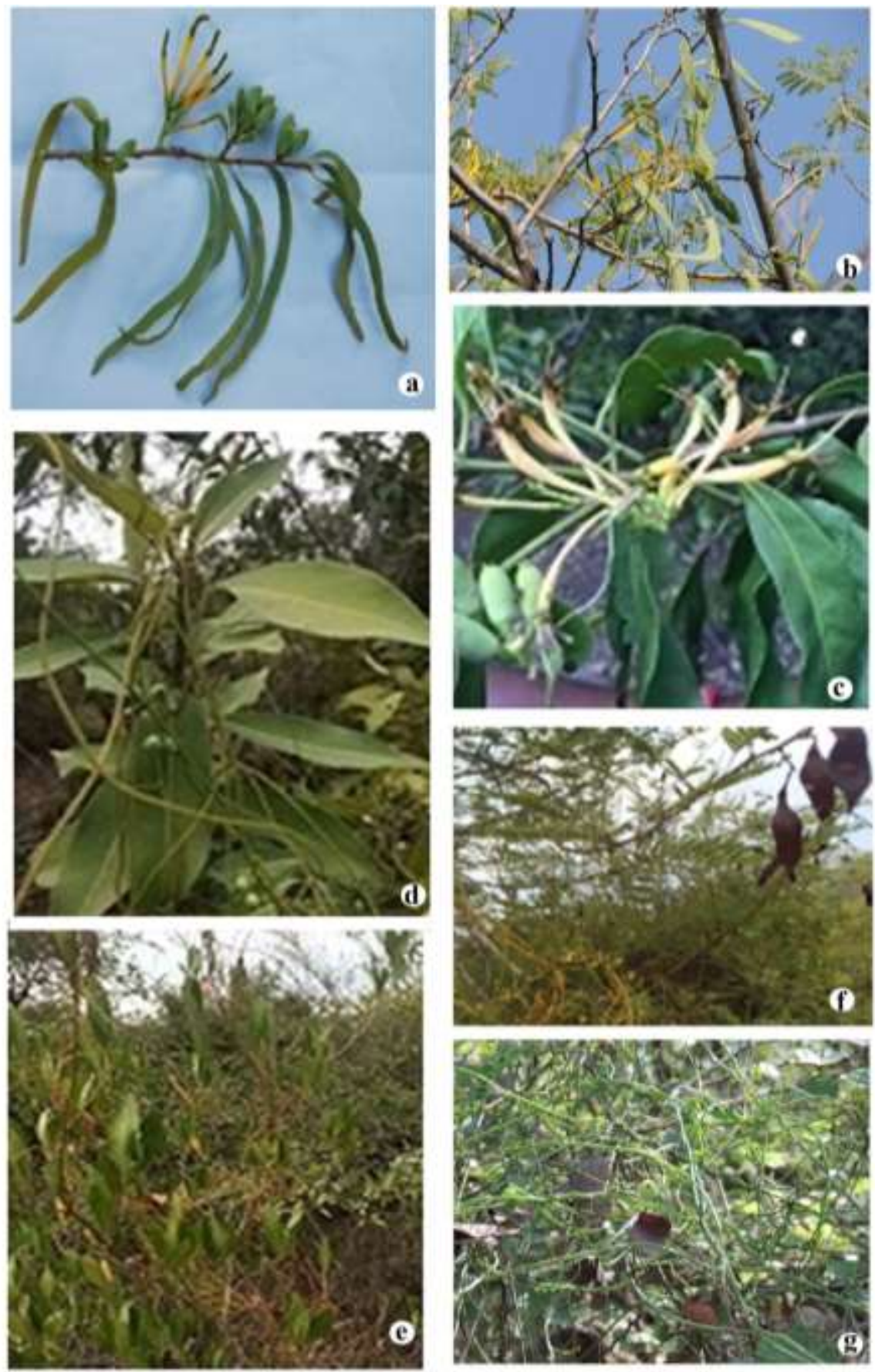

Fig 2:- (a) Dendrophthoe falcata- flowers and fruits; (b). D. falcata on host Acacia chundra - flowers and fruits; (C). D. falcata on host Azadirachta indica-flowers and fruits; (d). Cassytha filiformis infested on host Syzygium cumini; (e). C. filiformis infested on host Dodonaea viscosa; (f). C. filiformis infested on host Pterolobium hexapetalum and (g). C. filiformis infested on host Bauhinia racemosa.

Study revealed that $C$. filiformis was found infested on 26 hosts plants in the study area belonging to 18 families. Twenty-four plants are indigenous, one is exotic and another one is cosmopolitan. When compared to $D$. falcata, the parasite $C$. filiformis had exhibited a wide host ranges in the Annamalai reserve forest. It affects the host plants with various habits such as trees, shrubs, sub-shrubs, herbs and climbers (Fig $2 \mathrm{~d}$, e, f \& g). Out of 26 hosts infested by $C$. filiformis, 11 are trees, 12 are shrubs, 2 are climbers and one is a herb. Infestation of hosts by C. filiformis were found in all parts of the forests ranging from altitudes $200 \mathrm{~m}$ to $730 \mathrm{~m}$ above mean sea level (Table 2). 
Table 2:- Host plants of $C$. filiformis in Annamalai reserve forest.

\begin{tabular}{|c|c|c|c|c|}
\hline S. No. & Host plant & Family & Habit & Indigenous/exotic \\
\hline 1. & Cassia auriculata $\mathrm{L}$. & Caesalpiniaceae & Herb & Indigenous \\
\hline 2. & Cassia fistula $\mathrm{L}$. & Caesalpiniaceae & Tree & Indigenous \\
\hline 3. & $\begin{array}{l}\text { Pterolobium hexapetalum (Roth) } \\
\text { Santapau \& Wagh }\end{array}$ & Caesalpiniaceae & Shrub & Indigenous \\
\hline 4. & $\begin{array}{l}\text { Canthium coromandelicum (Burm.f) } \\
\text { Alston }\end{array}$ & Rubiaceae & Shrub & Indigenous \\
\hline 5. & Morinda tinctoria Roxb. & Rubiaceae & Tree & Indigenous \\
\hline 6. & Benkara malabarica (Lam.) Tirv. & Rubiaceae & Shrub & Indigenous \\
\hline 7. & Waltheria indica $\mathrm{L}$. & Malvaceae & Subshrub & Exotic \\
\hline 8. & Pavonia zeylanica (L.) Cav. & Malvaceae & Herb & Indigenous \\
\hline 9. & Acacia chundra (Rottler) Willd. & Mimosaceae & Tree & Indigenous \\
\hline 10. & Acacia ferruginea DC. & Mimosaceae & Tree & Indigenous \\
\hline 11. & Chloroxylon swietenia DC. & Rutaceae & Tree & Indigenous \\
\hline 12. & Glycosmis pentaphylla (Retz.) DC & Rutaceae & Shrub & Indigenous \\
\hline 13. & Wrightia tinctoria (Roxb.) R.Br. & Apocynaceae & Tree & Indigenous \\
\hline 14. & Carissa spinorum L. & Apocynaceae & Shrub & Indigenous \\
\hline 15. & Rivea hypocrateriformis (Desr.) Chosy & Convolvulaceae & Climber & Indigenous \\
\hline 16. & $\begin{array}{l}\text { Terminalia arjuna (Roxb. ex DC.) } \\
\text { Wight \& Arn }\end{array}$ & Combretaceae & Tree & Indigenous \\
\hline 17. & Euphorbia antiquorum L. & Euphorbiaceae & Shrub & Indigenous \\
\hline 18. & Diospyros ferrea (Willd.) Bakh. & Ebenaceae & Tree & Indigenous \\
\hline 19. & Erthroxylon monogynum Roxb. & Erythroxylaceae & Tree & Indigenous \\
\hline 20. & Flacourtia ramontchi L'Her. & Flacourtiaceae & Tree & Indigenous \\
\hline 21. & Bauhinia racemosa Lam. & Fabaceae & Shrub & Indigenous \\
\hline 22. & Hugonia mystax $\mathrm{L}$. & Linaceae & Shrub & Indigenous \\
\hline 23. & Syzygium cumini (L.) Skeels & Myrtaceae & Tree & Indigenous \\
\hline 24. & Azadirachta indica A.Juss. & Meliaceae & Tree & Indigenous \\
\hline 25. & Dodonaea angustifolia L.f. & Sapindaceae & Shrub & Cosmopolitan \\
\hline 26. & Grewia hirsuta Vahl & Tiliaceae & Subshrub & Indigenous \\
\hline
\end{tabular}

Seeds of C. filiformis were easily dispersed by white-browed bulbuls which were observed commonly at all parts of the study area and characteristic features such as survival of seedlings for even eight weeks without host substratum, ability to grow on soil independently and later become obligate parasite when it comes into contact with host plants might have helped this parasite to extend its host ranges. Whereas $D$. falcata which required sunbirds for dispersal of seeds and seedlings need immediate host substratum for successful survival might have resulted in failure of extending its host ranges beyond five trees. These two parasites never infest any of the host plants belonging to Monocotyledons. Though the angiosperm parasites were part of bio-diversity of the forest vegetation, its impact on the forest vegetation, transmission of diseases and economic loss to the woods of trees need further study.

Selvi and Kadamban (2009) had reported instances of double parasitism of these two parasites on host plants, viz., Anacardium occidentale $L$. and Azadirachta indica $L$ at Pondicherry Engineering College campus. Similar instances of double parasitism were found in the case of two indigenous species namely, Acacia chundra (Rottler.) Willd. and Diospyros ferrea (Willd.) Bakh. in the study area. Both D. falcata and C. filiformis had infested and grew extensively on these two host trees.

\section{Conclusion:-}

The parasite $D$. falcata had so far not extended its host ranges in the forest, beyond 5 host trees belonging to four families, but $C$. filiformis had extended its host ranges up to 26 host species belonging to 18 families. D. falcata was confined in the undisturbed western side of the Annamalai reserve forest, but $C$. filiformis had widened its habitats from plains to an altitude of $814 \mathrm{~m}$ AMSL. It depends on the host trees and the morphology of leaves (polymorphism) vary in D. falcata. Double parasitism was observed on two indigenous trees such as Acacia 
Chundra and Diospyros ferrea. Though parasites were part of the bio-diversity of the forest vegetation its impact on the economic loss to the woods of trees needs further study.

\section{Acknowledgements:-}

The authors are thankful to Sudha Ramen IFS., District Forest Officer and G. Udayakumar, ACF, Thiruvannamalai District for giving permission to undertake studies in the reserve forest; to P. Poornima IFS, District Forest Officer, Koraput, Odisha for reading the pre-final draft; Madha Suresh, Director, University of Madras for providing geographical data and to A. Ranjithkumar and M. Arunpandian, Thiruvannamalai for extending assistance during data collection.

\section{References:-}

1. Anuradha, J. 2005. Morphological and photo pigments study on Dendrophthoe falcata (L.F.) Ettingsh. (Loranthaceae) and its host plants at Shakti, Auroville M Sc Thesis Pondicherry University, Pondicherry, India.

2. Balasubramanian, P. 1990. Seed dispersal of Cassytha filliformis at Point Calimere. Journal of the Bombay Natural History Society 87: (3) 472.

3. Brand, A. R. 1938. Working plan for Nilambur Forest Division, Madras (1938-1939 and 1952-1953).

4. Calvin, C. L. and Wilson, C. A. 2009. Epiparasitism in Phoradendron durangense and Dendrophthoe falcata (Viscaceae). Aliso 27: 1-12.

5. David, J. P. Manakadan, R and Ganesh, T. 2015. Frugivory and seed dispersal by birds and mammals in the coastal tropical dry evergreen forests of southern India: A review Tropical Ecology 56(1): 41-55.

6. Ezekiel, M. H. 1935. Double parasitism of Loranthus and Viscum on Eugenia. Curr. Sci. 4: 62.

7. Gamble, J. S. and Fischer, C. E. C. 1959. The Flora of the Presidency of Madras, Reprinted Edition, Vol. I-III, Botanical Survey of India, Calcutta.

8. Kemp, C. D. 1960. Methods of determining leaf area of grasses from linear measurements. Annals of Botany 24: 491-499.

9. Kokubugata. G. and Yokota, M. 2012. Host Specificity of Cassytha filiformis and C. pergracilis (Lauraceae) in the Ryukyu Archipelago. Bulletin of the National Museum of Nature and Science Series B.Botany 38(2): 47-53.

10. Mahadevan, N. and Jayasuriya, K. M. G. G. 2013. Water-impermeable fruits of the parasitic angiosperm Cassytha filiformis (Lauraceae): confirmation of physical dormancy in Magnoliidae and evolutionary considerations. Australian Journal of Botany 61 (4): 322 -329.

11. Mathew, K. M. 1983. The flora of the Tamilnadu Carnatic, Vol. 3. The Rapinat Herbarium, St. Josephs College, Tiruchirapalli, India.

12. Mathur, A. K. 1949. Angiospermic parasites of our forests. The Indian Forester 75: 449-456.

13. Mehrotra, R. S. 1983. Plant pathology. Tata Mc Graw-Hill publication Co. Ltd 743-744.

14. Mukhtar, I., Khokhar, I. and Mushtaq, S. 2010. First report on Cassytha filiformis L. (Lauraceae), A parasitic weed from Lahore, Pakistan. Pakistan Journal of Weed Science Research 16 (4): 451 -457.

15. Nelson, S. C. 2008. Cassytha filiformis. Plant Diseases 42: $1-10$.

16. Nickrent D. L. 2002. Psychogenetic origin of parasitic plants. In: J.A. Lopez - saez, P. Catalan and L. Saez (eds). 'Parasitic plants of Iberian Peninsula and Balearic Islands' Mandi, Prensa, Madrid 29 -56.

17. Nickrent, D. L. and Musselman. 2004. Introduction to parasitic flowering plants. The Plant Health Instructor DOI: 10.1094/PHI-I-2004-0330-01.

18. Rangaswamy, N. S. and Rangan, T. S. 1963. In vitro culture of embryos of Cassytha filiformss L. Phytomorphol. 13(4): 445-449.

19. Selvi, B. and Kadamban, D. 2009. studied on the parasitic plants of Pondicherry Engineering College Campus, Puducherry. International Journal of Plant Sciences 4 (2): 547-550.

20. Sridhar, T. S. and Rao, V. R. 1979. Dendrophthoe falcata, a menace to fruit Orchards. Current Science 38: 1908.

21. Vijayasankar, R., Ravikumar, K. and Ravichandran, P. 2010. Plant Resources of Thiruvannamalai District, Tamil Nadu, India. Pub.Bishen Singh Mahendra Pal Singh, Dehra Dun, India.

22. Wellman, F. L. 1964. Parasitism among neotropical Phanerogams. Ann. Rev. Phytopath 2: 43 -56.

23. Werth, C., Pusateri, W.P., Eshbaugh, W. H. and Wilson, T. K. 1979. Field observations on the natural history of Cassytha filiformis L. (Lauraceae) in the Bahamas species. In: Proceedings of the Second International Symposium on Parasite Weeds. (Musselman, L.J., Worsham, A.D. and Eplee, R.E. eds.) $94-102$. 